Kwartalnik Młodych Muzykologów UJ

nr 47 (4/2020), s. 105-139

DOI 10.4467/23537094KMMUJ.20.019.13205

www.ejournals.eu/kmmuj

(iD) https://orcid.org/oooo-00o2-5646-6622

\title{
Karol Rzepecki
}

Katolickı Uniwersytet Lubelski Jana PaWta II

Recepcja twórczości Józefa

Wieniawskiego w świetle XIX-wiecznego piśmiennictwa - przegląd źródeł

\section{Abstract}

Reception of Joseph Wieniawski's work in the light of nineteenthcentury literature - a review of sources

The work of Polish composers active at the turn of the 2oth century has largely been forgotten, awaiting to be researched nowadays. Józef Wieniawski and his output, which used to attract the attention of Polish and foreign critics, is the case in point. This article seeks to provide a synthetic study of this issue on the basis of 19th century literature.

\section{Keywords}

Joseph Wieniawski, Henryk Wieniawski, Polish music 
Józef Wieniawski (1837-1912) - jeden z najwybitniejszych kompozytorów polskich II połowy XIX wieku - należy dzisiaj do twórców zapomnianych. Po skromnej monografii Léona Delcroixa ${ }^{1}$ powstałej jeszcze za życia, brat słynnego skrzypka Henryka, urodzony w Lublinie, nie doczekał się syntetycznego opracowania swojego życiorysu, czego próbę podjął autor niniejszego artykułu. Nie powstała żadna praca podejmująca zagadnienie recepcji twórczości J. Wieniawskiego. Dlatego też przestudiowane zostały główne czasopisma, $\mathrm{z}$ ośrodków, w których pianista prowadził działalność: Warszawy, Berlina, Paryża czy Brukseli. Wśród nich znalazły się dzienniki, tygodniki, a także prasa specjalistyczna. Wyrażam nadzieję, że niniejsze opracowanie przyczyni się do podjęcia dalszych badań skoncentrowanych wokół życia i działalności kompozytora.

Na łamach prasy, zarówno polskiej („Bluszcz”, „Echo Muzyczne i Teatralne”, „Echo Muzyczne, Teatralne i Artystyczne”, „Gazeta Lwowska”, „Kłosy”, „Kurier Warszawski”, „Ruch Muzyczny”, „Tygodnik Ilustrowany”), jak i zagranicznej ("Cecilia. Algemeen Muzikaal Tijdschrift van Nederlanden”, „Ilustrated London News”, „L'Art Moderne”, „L'Europe”, „Le Figaro”, „Le Guide Musical”, „Le Ménestrel”, "Morning Post”, „Musikalisches Betrachtungen”, „Musikalisches Centerblatt”, „Musikalisches Wochenblatt”, „Revue Gazette Musicale de Paris”, „Revue Musicale Sainte Cécile”, „Signale für die Musikalische Welt") regularnie ukazywały się artykuły bądź mniejsze wzmianki dotyczące poszczególnych dzieł Józefa Wieniawskiego. W literaturze cytowanej zastosowana została oryginalna pisownia, uznawana dzisiaj niekiedy za błędną pod względem ortografii i stylistyki.

Pierwszy taki komentarz, poświęcony Grand duo polonais op. 5 pochodzi z lipca $1855 \mathrm{roku}^{2}$, a zatem pojawił się dopiero po upływie trzech lat od powstania utworu. Anonimowy autor odnosząc się do wspólnego dzieła braci Wieniawskich dokonał szczegółowej analizy wyodrębniając kolejne części. Pisał: „Ten duet wychodzi w G-dur, przynosi tyle taktów wstępu, po którym następuje Kozak w e-moll, po czym rozbrzmiał temat główny Maciek w G-dur, po

1 Ker, Grand Duo Polonais pour Violon et Piano concertant composé par les frères Henri et Joseph Wieniawski, w: L. Delcroix, Joseph Wieniawski, J.B. Katto, Bruxelles 1908.

2 „Signale für die Musikalische Welt” 1855, nr 31, s. 241-242. 
czym Wariacje i kadencje Wieniawskiego"3. Zdaniem autora artykułu: „to były fajerwerki, takie $\mathrm{z}$ dziesięcioma milionami iskier, takie z dobrymi racami" ${ }^{4}$.

Jedna z pierwszych prób kompozytorskich Wieniawskiego została zatem przyjęta przychylnie przez niemieckiego krytyka, który w dalszej części swojego wywodu zauważył patriotyczny wydźwięk niektórych fragmentów, stwierdzając: ,jakże gorąca jest polska krew! I jaki piękny jest taniec! Zatem do szeregu"5. Nie oznacza to jednak, że również w latach późniejszych zdanie dotyczące twórczości Wieniawskiego pozostawało w tak entuzjastycznym tonie. Należy je zdecydowanie rozgraniczyć na ocenę dokonywaną przez krytyków polskich i zagranicznych, co wykaże późniejsza analiza.

Pierwszą taką informację zamieszczono w maju 1857 roku na łamach „Revue Gazette Musicale de Paris” przy okazji recenzji dotyczącej koncertu, jaki odbył się 25 lutego w Société Félix Meritis, w Amsterdamie. Wówczas „Pan Wieniawski zagrał pierwszą część skomponowanego niedawno przez siebie w Berlinie Koncertu fortepianowego g-moll. Orkiestrą dyrygował Henry Litolff, a jego brat Henryk grał pierwsze skrzypce”. Kilka tygodni później, na łamach „Ruchu Muzycznego”, odnosząc się do Poloneza C-dur op. 13 krytyk stwierdził, że „trzeba się dobrze rozpatrzyć w tej kompozycyi, by w niej upodobanie znaleźć" 7 . Na podstawie dalszej części wypowiedzi można jednak domniemywać, że owa opinia wynikała z poziomu kształtującego się dopiero warsztatu lublinianina. Jak dalej czytamy: „widać tu staranie i dążność do lepszej muzyki. Efekt całości miły"8. Niespełna rok późniejw lutym, na łamach tego samego czasopisma pojawiła się obszerna notatka poświęcona pianiście. Autor przywołał w niej najważniejsze dotychczasowe sukcesy, ale odniósł się również do oceny warsztatu kompozytorskiego. Wspomniany Polonez był jednym z ostatnich ukończonych na ów moment utworów. Dowiadujemy się, że „między trzynastoma wydanemi już, znajdują się przynoszące zaszczyt kompozytorowi tak polotem jak i rozmiarem"9. Większą uwagę autora

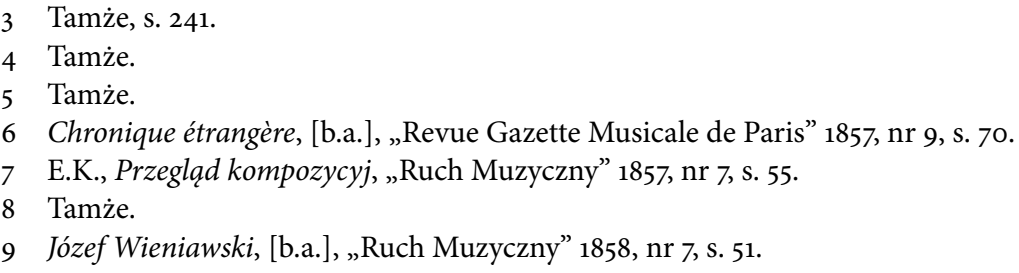


przykuły rękopisy, będące „dowodem najpiękniejszych dążności, że już o ich poetycznym duchu nie mówimy"10. Kilka tygodni później pojawiła się relacja $\mathrm{z}$ koncertu, jaki miał miejsce na początku marca 1858 roku. Obok oceny interpretacji Koncertu fortepianowego g-moll op. 25 Feliksa Mendelssohna-Bartholdy’ego osobny akapit poświęcony został własnym dziełom Wieniawskiego. W wykonaniu autora zostały zaprezentowane: „romans z waryacyami, walc koncertowy oraz adagio elegiczne $\mathrm{z}$ następującèm po nièm rondem wesołego charakteru"11. Spotkały się one z oceną:

\footnotetext{
Wszędzie panuje sprężystość w miarę użyta, wiele elegancyi i fantazyi pilnującej się w skarbach, choć bardzo świetnej. Oryginalność myśli nie zbyt wyskakująca, ale widoczna szczególniej w pasażach pełnych świeżości i blasku, kompozycie te wyróżnia stanowczo między innemi. Szkoda, że p. W. nie pokazał nam jakiej swèj pracy z towarzyszeniem orkiestry, albo nawet czysto orkiestrowèj ${ }^{12}$.
}

Chodziło tutaj o: Valse de concerto op. 3, Fantasie et variations de Concert sur des Motivs 'La Sonenbulla' de Bellini op. 6 oraz RomanceÉtude op. 10 - owoc studiów w konserwatorium paryskim pod kierunkiem Pierre’a Zimarnanna. Odpowiedź na zawarty w recenzji niedosyt pojawiła się jeszcze w tym samym miesiącu, podczas kolejnego z koncertów. Był to jednocześnie pierwszy występ w Warszawie, zawierający w programie literaturę symfoniczną Wieniawskiego. Otóż 24 marca 1858 roku w Resursie Kupieckiej wykonał Koncert fortepianowy c-moll op. 37 Ludwika van Beethovena - jak dowiadujemy się wówczas dzieła "prawie zupełnie u nas nieznanego"13, uzupełniając utwór o własną kadencję. Pomimo powstania ok. 1857 roku kadencja ukazała się drukiem w Londynie dopiero dwadzieścia lat później, a na stronie tytułowej została zamieszczona data wykonania podczas koncertu w Londyńskim Towarzystwie Filharmonicznym 9 lipca 1877 roku $^{14}$. Jej ocena przedstawia się następująco:

10 Tamże.

11 Koncert Pana Józefa Wieniawskiego, [b.a.], „Ruch Muzyczny” 1858, nr 10, s. 77.

12 Tamże, s. 78.

13 Koncert Pana Józefa Wieniawskiego w Resursie Kupieckièj, [b.a.], „Ruch Muzyczny” 1858 , nr 13, s. 99.

14 J. Wieniawski, Cadenza pour le 3me Concerto pour le Piano de Beethoven, Stanley Lucas, London 1878. 
W tej Cadenzy streścił p. W., całe allegro owego koncertu, temat pierwszego tutti biorąc za osnowę, którą haftują inne, główniejsze rysy, z tego samego ustępu pożyczone. Splecenie tego w całość mającą jakby własne peryody, własne światło i odcienie, a dającą jakby miniaturę tego, co Beethoven szeroko rozwinął, samo już mówi o studyach p. W., nad tém dziełem i tłumaczy cudownie przedstawioną całość ${ }^{15}$.

Wówczas pod batutą kompozytora zabrzmiała również zaginiona dzisiaj Uwertura D-dur, która spotkała się z nie mniejszym zainteresowaniem:

\begin{abstract}
Jako kompozytor rozciekawił głównie p. W., uwerturą swą koncertową (D tw.) na orkiestrę. Cechą jej łatwość i prostota pomysłów, krótkie rozmiary i jakby ucinkowość. Mało rozwinięta, odznacza się jednak szczegółami, w których troskliwość instrumentacyi głównie uderza baczność słuchacza. Uważamy ją jako studyum orkiestrowe, nie jako płód natchnienia, jako igraszkę, objaw sympatyi dla takiego wzoru, nie jako płód samoistny i mający okazać zdolności kompozytorskie autora ${ }^{16}$.
\end{abstract}

Jako jedno z pierwszych dzieł o charakterze symfonicznym Uwertura, w przeciwieństwie do Cadenzy, oceniona została pobłażliwie, co potwierdzają późniejsze recenzje „Ruchu Muzycznego”. Kontynuacją prezentacji symfoniki był trzeci - ostatni poranek muzyczny, podczas którego wykonał Koncert fortepianowy g-moll op. 20. Utwór trzyczęściowy - utrzymany w klasycznej konwencji - został poddany analizie anonimowego krytyka: „myśli główne (temata) w każdej z trzech części tego koncertu (Allegro moderato, Andante, Allegro molto vivace), odpowiednie są rozległości form, które wypełniać mają; to ich techniczna zaleta"17.

Recenzent zwrócił jednocześnie uwagę na walor brzmieniowy. Mówiąc o kolejnych częściach stwierdził, że „poetyczne ich znaczenie nie mniej jest ważne, a słuchając ich rozwinięcia szlachetnego, zważając jego ciągły interes, musimy z góry przyznać, że nie błahy był do rozprawy powód"18, natomiast podsumowując tą część wypowiedzi dodał:

15 Koncert Pana Józefa Wieniawskiego w Resursie Kupieckièj, [b.a.], „Ruch Muzyczny” $1858, \mathrm{nr} 13$, s. 99.

16 Tamże, s. 100.

17 Trzeci koncert p. Józefa Wieniawskiego, [b.a.], „Ruch Muzyczny” 1858, nr 15, s. 114.

18 Tamże. 
Winniśmy jednak powiedzieć, że jak w rozwinięciu jest zawsze wzniosłość, powaga, siła niekiedy do potęgi rosnąca. Tak w zadaniu jest godność i stanowczość charakteru. Najwydatniejszy on w 3cim ustępie i stąd poszła największa finału oryginalność. Wartko i krzepko zakończył co Allegro I-e pompatycznie, świetnie rozpoczęło, co Andante czująco opowiedziało ${ }^{19}$.

Analizie została poddana również partia orkiestry. Czytając o instrumentacji odnajdujemy optymistyczne informacje. Dowiadujemy się, że „jest to gra kolorów i oświetlenia od rutyny, zależąca tyle pewnie, jeśli nie więcej, jak od pomysłów"20. Autor dostrzegł w dziele elementy oryginalności i własnej inwencji kompozytora, jednak jego zdaniem nie wykraczają one poza panujące wówczas konwencje: „W pracy Pana Wieniawskiego tak troskliwie wykończonej nie brak jednakże staranności i o to, równie jak o jasność w figurach fortepianu, które jeśli nie mają uderzającej oryginalności, bynajmniej w pospolitość nie wpadają i samoistności kompozytora nie zaprzeczają $a^{21}$.

Była to pierwsza tak wnikliwa analiza twórczości młodego pianisty. Drugi raz Koncert fortepianowy g-moll op. 20 zabrzmiał wśród warszawskiej publiczności jeszcze 10 grudnia 1858 roku. Tym razem Wieniawski został określony mianem młodego artysty, zmierzającego konsekwentnie wyznaczoną sobie ścieżką do osiągnięcia określonego celu - uznania środowiska artystycznego i publiczności. Jego zdaniem pianista wpisał się dzięki temu w krąg kompozytorów sięgających po większe formy, tworzących niewielką elitarną grupę. Dodał, że jest to: „Dzieło dostojne jako rodzaj, piękne pomysłami, przeprowadzeniem ich myślące, znakomite rozmiarem, wprowadza autora stanowczo w szereg mistrzów szkoły klasyczną zwanèj, głównie dlatego tak zwanèj, że pilnuje formy z miłością kształconej, wyrozumowanèj i ustalonèj”22.

Recenzent, kontynuując słuchanie Koncertu, porównał go do wpatrywania się w obraz, co powoduje „rozkosz i korzyść dla ducha”23. Wieniawski u progu swojej działalności kompozytorskiej, przez polskich krytyków postrzegany był jako twórca pozostający w ramach panujących wówczas konwencji. Należy również zauważyć, że przywołane

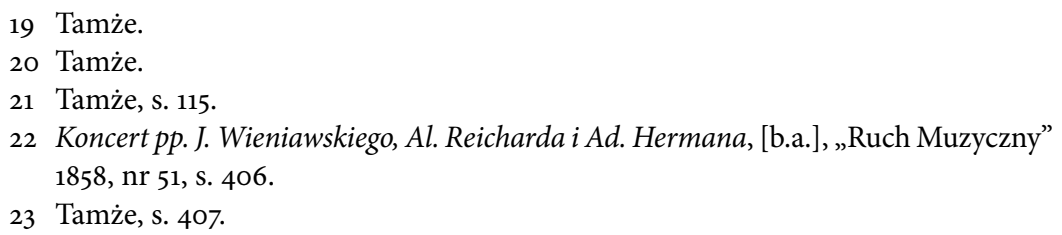


dzieło było jednym z pierwszych koncertów fortepianowych napisanych przez kompozytora polskiego po 1850 roku. W 1859 roku uwage na to zagadnienie zwrócił również Józef Doroszenko (wł. Marceli Jasiński), który skomplementował też instrumentację. Zarzucił jednak nazbyt skromne wykorzystanie instrumentu solowego:

\begin{abstract}
Instrumentowanie piękne i dobrze obmyślane. Orkiestra to nie znaczy resztę potakującą jednemu, a przeciwnie: solowy fortepian i reszta zaproszonych do partytury stanowią towarzystwo ożywione jednym duchem, rozmawiające o jednym przedmiocie. Nawet mielibyśmy do zarzucenia fortepianowi, że zbyt jest skromnym i mnièj się odzywa, niż by miał słuszne prawo do tego. Ale szanujemy wolę i zmysł autora, którego z radością witamy ${ }^{24}$.
\end{abstract}

Marceli Jasiński (1837-1867) przedstawił w ten sposób warsztat Wieniawskiego postrzegany z punktu widzenia innego twórcy.

Kolejna wzmianka dotycząca twórczości Wieniawskiego w prasie zagranicznej dotyczyła Valse de Concerto op. 3 lub Valse de Salon op. 7. Jak dowiadujemy się z informacji na łamach „Revue et Gazette Musicale de Paris”: „Wydawca Girod opublikuje słynny walc Józefa Wieniawskiego, który odniósł wielki sukces na ostatnim koncercie wywołując aplauz i entuzjazm wśród publiczności" ${ }^{25}$. Przed 1860 rokiem Wieniawski nie skomponował bowiem żadnego innego walca. Wspomniane wydanie nie doszło jednak do skutku: działająca w latach 1855-1919 paryska oficyna nigdy nie wydała takiego utworu. Jednocześnie w rubryce Przegląd kompozycyj na łamach „Ruchu Muzycznego” anonimowy autor zamieścił swoją opinię na temat dwóch innych pozycji:

Wspomnienie Lublina op. 12 Józefa Wieniawskiego

Harmonia u Wieniawskiego zwykle jest wytworna, a jednak nie przeładowana; figuracya jeśli nie nowa to interesująca bardzo i zręczność fortepianowego składu nie do życzenia nie zastanawiająca. Temat bardzo piękny, więc i waryacye być muszą; toć pamiętamy, jak je nie dawno jeszcze grał sam autor i nie potrzebujemy ich polecać. Ostrzec jednak potrzeba, że waryacya pierwsza dostatecznie trudna lubo się nie zdaje na oko; za to druga, choć niby straszniejsza z pozoru łatwiutka stosunkowo.

24 J. Doroszenko, Wieści z kijowskich koncertów, „Ruch Muzyczny” 1859, nr 12, s. 105. 25 Chronique étrangère, [b.a.], „Revue Gazette Musicale de Paris” 186o, nr 19, s. 169. 
Nosi na sobie wszystkie cechy troskliwego opracowania, bo należy do utworów mających styl i myśl artystycznie rozwinięta. Jeśli poprzednio wymieniony utwór jest jakby cackiem troskliwie wyrobionem, to ten drugi istotnie dziełem muzycznem i muzykalnem. Niechże się nikt nie przeraża tym predykatem; bo autor zbyt mocny w technice, by miał w niej grających w błoto wprowadzićć ${ }^{2}$.

Była to pierwsza tak wnikliwa analiza niniejszych utworów, zważywszy na to, że Impromptu op. 19 nie wydano jeszcze drukiem. Kilka tygodni później krytyk na łamach „Ruchu Muzycznego” poinformował o wykonaniu w Paryżu wspomnianej już Uwertury D-dur, w której „chwali pomysły i ich prowadzenie - ale więcéj pragnie zwięzłości”27. Natomiast 26 kwietnia 1860 roku Józef Wieniawski zaprezentował się jako pianista i kompozytor w paryskiej Sali Herza. Dowiadujemy się, że „wrócił tutaj po dziesięciu latach spędzonych za granicą"28. Wystąpił tam również jako dyrygent „wykonując swój Koncert g-moll z wielkim powodzeniem"29. Do stolicy Francji powrócił pod koniec tego roku, dając cykl trzech koncertów w Salonie Pleyela. Występy z uwagą śledził miejscowy kompozytor i krytyk muzyczny, Adolph Botte (1823-1896). Według niego „Impromptu i Pensée fugitive kompozycji autora ponownie ukazały jego podwójne oblicze: talent pianisty i warsztat kompozytora" ${ }^{30}$. Jeszcze 27 grudnia 1860 roku Wieniawski wystąpił w Liceum Lois-le-Grand, gdzie zaprezentował "Souvenir de Lublin i walc koncertowy, który zyskał najwyższe uznanie" ${ }^{31}$. Ponadto, w opinii autora „Pan Wieniawski się okazał środkującym między klasykami i pisarzami lubiącemi dzisiejsze muzyki formy"32, co zapewne stanowi odniesienie do formy wariacji. Przywołana opinia nie jest jednak odosobnioną. W ostatnim z trzech koncertów, w Sali Pleyela 19 lutego 1861 roku - artysta zaprezentował swojego Poloneza As-dur op. 21 - według recenzenta „Ruchu Muzycznego” utwór „bardzo

26 Przegląd Muzyczny, [b.a.], „Ruch Muzyczny” 186o, nr 19, s. 315.

27 Tamże, s. 320.

28 Soirées et concerts, [b.a.], „Le Ménestrel” 1860, nr 27, s. 159.

29 Soirées et concerts, [b.a.], „Le Ménestrel” 186o, nr 28, s. 167.

30 A. Botte, Koncert Józefa Wieniawskiego, „Revue Gazette Musicale de Paris” 1860, nr 52, s. 440.

31 Nouvelles, [b.a.], „Revue Gazette Musicale de Paris” 1860, nr 53, s. 449.

32 Tamże. 
trudny, bardzo świetny, ale i bardzo melodyjny i dobrze prowadzony mimo niektórych rozwlekłości"33. Była to pierwsza ocena utworu, zamieszczona jeszcze przed wydaniem nakładem rosyjskiej oficyny Alexandra Gutheila, w 1862 roku. Wrzesień 1861 roku Wieniawski spędził w Wiesbaden. Wówczas pojawiła się pierwsza informacja o jego współpracy z Mikołajem Rubinsteinem (1835-1881). Dowiadujemy się, że "Józef Wieniawski komponował pilnie, a od Nikolasa Rubinsteina słyszeliśmy wykonanie wielu zebranych jego dziel" 34 .

Z czasem obok opinii dotyczących poszczególnych kompozycji Wieniawskiego pojawiały się - jak już wspomniano - w przypadku walca informacje dotyczące ich wydania. $Z$ początkiem kwietnia 1863 roku dowiadujemy się, że wśród „nowości ostatniego tygodnia”35 odnaleźć można Impromptu por Piano op. 19 Wieniawskiego, co tym razem było prawdą, bowiem utwór ukazał się nakładem lipskiej oficyny Friedricha Kirstnera. W październiku, za przyczyną tego wydawnictwa światło dzienne ujrzał zbiór mazurków op. 23. W opinii krytyka Huit Mazurkas pour Piano par Wieniawski op. 23 to utwory „,rozmaite, twórcze i charakterystyczne dla narodu tendencje w tych mazurkach, tak jak niezupełnie duża trudność tego samego, dobrze nadaje się do zyskania przyjaciół"36. Cykl ośmiu kompozycji, zawartych w dwóch zeszytach był jednym z pierwszych owoców nowo rozpoczynającego się etapu w życiu kompozytora, związanego z przeprowadzką do Moskwy, o czym oficjalna informacja pojawiła się w styczniu $1865 \mathrm{roku}^{37}$.

Obszerny artykuł o twórczości Wieniawskiego pojawił się w grudniu 1868 roku na łamach czasopisma „Bluszcz”. Wówczas nosił on już miano nie tylko cenionego kompozytora, ale również pedagoga profesora Konserwatorium Muzycznego w Moskwie, który ponadto prowadził w tym mieście własną szkołę muzyczną. Anonimowy krytyk nie szczędził wówczas komplementów pod adresem zarówno jego twórczości, jak też warsztatu pianistycznego. Jego zdaniem: „Pan Wieniawski umie, jak mało kto, postawić jedno na pierwszym planie, inne na drugim, a nie pozwolić, aby jedno drugie zagłuszało" 38 , posuwając się dalej do poszukiwań analogii pomiędzy twórczością

33 Gazeta Muzyczna, [b.a.], „Ruch Muzyczny” 1861, nr 10, s. 151.

34 Dur und Moll, [b.a.], „Signale für die Musikalische Welt” 1861, nr 38, s. 523.

35 Dur und Moll, [b.a.], „Signale für die Musikalische Welt” 1863, nr 18, s. 291.

36 Dur und Moll, [b.a.], „Signale für die Musikalische Welt” 1863, nr 42, s. 681.

37 Zob. Dur und Moll, [b.a.], „Signale für die Musikalische Welt” 1865, nr 4, s. 58.

38 J. Kleczyński, Ruch Muzyczny, „Bluszcz” 1868, nr 51, s. 333. 
Wieniawskiego a obrazami. Nie został jednak wymieniony żaden konkretny utwór. Istotny artykuł, z punktu widzenia oceny dorobku kompozytorskiego, przez jemu współczesnych autorów pojawił się w styczniu 1869 roku, na łamach „Tygodnika Ilustrowanego”. Jego autorem był rówieśnik i współpracownik pianisty - Jan Kleczyński (1837-1895), który jak można się przekonać wraz z upływem lat diametralnie zmienił swoje zdanie na temat twórczości i warsztatu pianistycznego kolegi. W pierwszej swojej oficjalnej wypowiedzi na temat Koncertu fortepianowego g-moll op. 20 stwierdził, że „finał pełny jest życia" ${ }^{39}$. Ponadto w dorobku pianisty zauważył logikę i konsekwencję. Jak dodał: „wszystko obmyślane jest z góry i rzadko spotkać można poryw fantazyi" 40 . W marcu 1871 roku, jak stwierdził Kleczyński: „Pan Wieniawski grał znakomicie Etiudę Szopena, bardzo pięknie Impromptu i Nocturne, ale własnym Polonezem nie zrobił na nas pożądanego wrażenia”41. Dodał jednak, że „inna kompozycya pana W.: romans odśpiewany przez pannę $\mathrm{H}$. Troschel bardzo się nam podoba, chcielibyśmy tylko drobniutką uwagę zrobić autorowi, że we francuskim języku wyrazy: comme nous stanowią 3 a nie dwie sylaby"42. Pozwala to na stwierdzenie, że dorobek Wieniawskiego był poddawany wnikliwej analizie dokonywanej przez jednego z najbardziej wpływowych krytyków muzycznych ówczesnej Warszawy. Niedługo później, w podobnym tonie wybrzmiała jego wypowiedź, na temat Cadenzy skomponowanej do Koncertu fortepianowego c-moll op. 37 Ludwika van Beethovena. Jak twierdził:

\footnotetext{
Cadenza w pierwszej części skomponowana przez pana W., jest bardzo piękna, może jej zakończenie cokolwiek jest za nowożytne, lubo usprawiedliwione potrzebą przy końcu wywołania świetnego efektu ${ }^{43}$.
}

Przywołany utwór był jednym z najczęściej wykonywanych przez Wieniawskiego koncertów na przestrzeni całej jego kariery. Od tego momentu na dłuższy czas prasa krajowa, jak i zagraniczna zaprzestała zamieszczania informacji dotyczących dokonań kompozytorskich Wieniawskiego.

39 J. Kleczyński, Ze świata muzycznego, „Tygodnik Ilustrowany” 1869, nr 57, s. 50.

40 Tamże.

41 J. Kleczyński, Ruch Muzyczny, „Bluszcz” 1871, nr 13, s. 103.

42 Tamże.

43 J. Kleczyński, Ruch Muzyczny, „Bluszcz” 1871, nr 18, s. 142. 
U progu 1875 roku rozpoczął się nowy etap w życiu Józefa Wieniawskiego. Przez kolejne trzy lata pełnił funkcję dyrektora artystycznego Warszawskiego Towarzystwa Muzycznego. Na jego barkach spoczęło zadanie organizacji cyklicznych koncertów. Z czasem, w ich trakcie znalazł sposobność do prezentacji własnej twórczości, co zauważył Jan Kleczyński. Jeden z takich występów miał miejsce 6 kwietnia 1876 roku. W części solowej, obok dzieł Chopina i Beethovena, Wieniawski zaprezentował własne utwory: Deuxième Tarantelle op. 35 i Polonaise pour le Piano op. 21. Krytyk odnosząc się do nich stwierdził, że „,z dzieł wykonanych na sam fortepian nie godzi się przypomnieć dwóch oryginalnych kompozycyj pana Wieniawskiego: drugiej Tarantelli, a zwłaszcza Poloneza (As-dur), który jest dziełem niepośredniej wartości”44. Kolejny raz Wieniawski zaprezentował fragment swojego dorobku w następnym sezonie, podczas koncertu jaki miał miejsce 20 września. 5 października „Kurier Warszawski” zamieścił obszerne sprawozdanie z 72. wieczoru w Towarzystwie Muzycznym. Pierwszy raz pojawiła się informacja o wykonaniu Kwartetu smyczkowego a-moll op. 32. Od niego rozpoczął się koncert, a „Pan Wieniawski całkowicie zapanował nad sercami słuchaczów" ${ }^{45}$. Wydarzenie to można uznać za prawykonanie Kwartetu. W części solowej zaprezentował Mazurka A-dur op. 23 nr 1 dedykowanego Marii Sułkowskiej ${ }^{46}$, którego „tak mógł to tylko sam kompozytor odegrać" 47 . Była to kolejna okazja dla mieszkańców stolicy do zapoznania się z dorobkiem jednego z czołowych twórców epoki w tym mieście. Do dzisiejszego dnia, w bibliotece Warszawskiego Towarzystwa Muzycznego zachował się tylko wyciąg fortepianowy Kwartetu smyczkowego ${ }^{48}$. Drukiem kompozycja ukazała się w 1882 roku.

Warto w tym miejscu przypomnieć, że Józef Wieniawski, jako pierwszy spośród dotychczasowych dyrektorów Warszawskiego Towarzystwa Muzycznego, podjął się realizacji pełni założeń statutowych: powołania do istnienia dwóch jednostek - chóru i orkiestry. We wrześniu 1877 roku „Kurier Warszawski” poinformował o planach wykonania Semiramidy podczas środowego koncertu, w dniu 3 października. Jak czytamy:

44 J. Kleczyński, Ruch Muzyczny, „Bluszcz” 1876, nr 16, s. 124.

45 „Kurier Warszawski” [b.a.] 1876, nr 219, s. 2.

46 Rękopis utworu znajduje się w Bibliotece Warszawskiego Towarzystwa Muzycznego (dalej: BWTM), sygn.

47 „Kurier Warszawski” [b.a.] 1876, nr 207, s. 1.

48 BWTM, sygn. R 3448. 
W przyszłą środę w naszém Towarzystwie Muzyczném, odbędzie się drugi $\mathrm{w}$ rozpoczynającym się sezonie wieczór, poświęcony w znacznej części utworom zbiorowym wokalnym. Między innémi wykonaną będzie nowa kompozycyja na głosy p. Józefa Wieniawskiego Semiramida ${ }^{49}$.

Zaprezentowana wówczas wersja utworu nie przetrwała do dzisiaj. Dzieło spotkało się z następującą oceną:

Jestże to ustęp z opery, czy z poematu symfonicznego, czy po prostu zwykły chór, którego tytuł bez szkody zamienić by można na inny? Co do nas wyznajemy, że związku między treścią wewnętrzną kompozycji a jej nazwą nie mogliśmy odnaleźć a poszukiwania utrudnił jeszcze $\mathrm{w}$ akompaniamencie organ, którego odgłos towarzyszący pieniom asyryjskim nie łatwo da się wytłumaczyć. Pominąwszy zresztą te wschodnie intencje, kompozycja pana Wieniawskiego, nie odznacza się jako ustęp chóralny głęboką myślą i słucha się bez wrażenia ${ }^{50}$.

Było to pierwsze i jedyne dzieło chóralne Wieniawskiego, w którym odwołał się do historii królowej Babilonu - Semiramidy. Być może ze względu na poruszaną tematykę utwór został skrytykowany, bowiem wykonany podczas tego koncertu psalm Henryka Jareckiego na analogiczną obsadę zyskał uznanie krytyka. Kompozytor sięgnął po temat rzadko poruszany przez kompozytorów polskich w zakresie literatury wokalno-instrumentalnej.

Druga połowa 1878 roku przyniosła zmiany w życiu Józefa Wieniawskiego. Zrezygnował z funkcji dyrektora Warszawskiego Towarzystwa Muzycznego, uzasadniając swoją decyzję względami zdrowotnymi i nie kandydując na kolejną kadencję. Miał zatem więcej czasu na działalność kompozytorską, pedagogiczną i koncertową, pozostając do końca życia niezależnym od jakiejkolwiek instytucji. W grudniu tego samego roku pojawiła się informacja o tym, że „działalność kompozytorska Józefa Wieniawskiego zaczyna się wzmagać" ${ }^{1}$. Niemal równolegle w Londynie, Paryżu i Lipsku ukazały się drukiem cztery jego kompozycje: Sonate pour Piano et Violoncelle op. 26, Cadenza pour le 3me Concert pour le Piano

49 „Kurier Warszawski” [b.a.] 1877, nr 211, s. 2.

50 „Kurier Warszawski” [b.a.] 1877, nr 218, s. 1.

51 „Kurier Warszawski” [b.a.] 1878, nr 29o, s. 2. 
de Beethoven op. 37, Deuxiéme Impromptu op. 34 oraz Deuxiéme Etude de Concert op. 36, z czasem wchodząc na stałe do repertuaru koncertowego ich autora.

17 stycznia 1881 roku Wieniawski zaprezentował się lwowskiej publiczności w Sali Ratuszowej, gdzie nie zabrakło kompozycji wykonawcy. Uwagę krytyka przykuł Polonez H-dur op. 27 wydany drukiem kilka tygodni wcześniej w lipskiej oficynie Christiana Kahnta. Jak czytamy:

\footnotetext{
Z utworów własnych koncertanta, który tak w ciągu produkcyi, jak mianowicie, po skończeniu jej, był przedmiotem owacyi, ze strony licznie zebranych słuchaczów - podobał się zwłaszcza piękny polonez (trzeci), pełny prawdziwie kunsztownego nastroju ${ }^{52}$.
}

O utworze tym odmienne zdanie miał Jan Kleczyński, o czym już wspominano.

Kolejne miesiące Józef Wieniawski spędził w Europie Zachodniej dając koncerty solowe i kameralne. Od czasu występu we Lwowie, po własną kompozycję sięgnął dopiero 20 lutego 1882 roku, kiedy wystąpił podczas inauguracji koncertów poniedziałkowych w paryskiej Sali Herza $^{53}$. Obok utworów Haydna, Mozarta, Chopina i Liszta „drugi raz w Paryżu Pan Wieniawski zagra swój Deuxiéme Valse de Concert, który zasługuje na pełne uznanie" 54 . Kilka dni później - 25 lutego $1882 \mathrm{roku}$ - jeden z paryskich dzienników poinformował, że „czwarty koncert Pana Józefa Wieniawskiego odbędzie się dziś wieczorem w Sali Herza. W programie znajduje się Sonata wiolonczelowa op. 26, której wysłuchamy w wykonaniu autora i Pana Hollmana" ${ }^{55}$. Holenderski wiolonczelista - Joseph Hollman - był jednym z najczęściej towarzyszących Wieniawskiemu artystów w wykonaniu tego utworu, za co obydwu nagradzano gromkimi brawami, głównie przez francuską i belgijską publiczność. Ten sam utwór wykonał w letniej rezydencji van der Heydenó $\mathrm{w}^{56} \mathrm{w}$ Ostendzie. Tym razem w roli solisty wystąpił absolwent Królewskiego Konserwatorium Muzycznego w Brukseli Éduard Jacobs. Dowiadujemy się, że „utwór spotkał się z gromkim aplauzem

52 F. Bylicki, Ze sceny koncertowej, „Gazeta Lwowska” 1881, nr 13, s. 2.

53 Zob. Échos des theatres, [b.a.], „Le Gaulois” 1882, nr 888, s. 4.

54 Tamże, s. 4.

55 Revue des theatres, [b.a.], „Le Petit Journal” 1882, nr 70o1, s. 3.

56 Zob. K. Rzepecki, Józef Wieniawski (1837-1912) - epoka, człowiek i dzieło. Studium historyczno-muzykologiczne, Lublin 2019, s. 203. 
ze strony publiczności” ${ }^{57}$. Lipskie „Musikalisches Centerblatt” w maju poinformowało o sukcesie, jaki przyniósł Wieniawskiemu cykl koncertów zorganizowany w salonach Erarda i Herza, gdzie prezentował również własne kompozycje. $\mathrm{W}$ programie czwartego $\mathrm{z}$ dziesięciu koncertów znalazła się „bardzo atrakcyjna Sonata Pana Wieniawskiego na fortepian i wiolonczelę, której partię przyjął Pan J. Hollman"58, natomiast na „kolejnym koncercie artysta zachwycił nas swoją Sonata op. 24 na fortepian i skrzypce w realizacji z udziałem Jenő Hubaya"59, co potwierdza powodzenie Wieniawskiego za granicą i jego sukces w stolicy Francji. Niemniej jednak autor wypowiedzi nie wskazuje kolejnych dat występów.

Koniec stycznia 1883 roku upłynął pod znakiem koncertów symfonicznych. Józef Wieniawski wystąpił dwukrotnie: 28 i 30 stycznia, w Le Grand Harmonie, pod batutą Josepha Martensa. W programie drugiego z koncertów znalazł się: Koncert fortepianowy g-moll op. $20^{60}$. Pomiędzy nimi - 29 stycznia - Józef Wieniawski na tej samej scenie dał koncert kameralny. Po wykonaniu swojej Sonaty skrzypcowej op. 24 „kompozytor Wieniawski był równie gorąco oklaskiwany jak Wieniawski pianista" ${ }^{61}$. Utwór, już drugi raz wykonany w tym miejscu - co zauważył krytyk - spotkał się z następującą opinią:

\begin{abstract}
Dzieło napisane jest w swobodnym i barwnym stylu Rubinsteina i Chopina, które w pewien sposób przywołuje, a sonata ta, od początku do końca, ma w sobie ogromną czystość przesłania oraz doskonałość formy, które zdradzają rękę doświadczonego i mądrego autora. Partia skrzypiec została zagrana $\mathrm{z}$ wielkim wdziękiem i czystością przez M. Jenö Hubaya, który kapitalnie wyraził poetycką i marzycielską stronę utworu ${ }^{62}$.
\end{abstract}

W styczniu 1884 roku „L’Art Moderne” poinformowało o pojawieniu się drukiem kolejnego utworu: „Wydawca Breikopf \& Härtel właśnie ujawnił Nocturne e-moll Pana Józefa Wieniawskiego, tworzący jego

57 Le Journée, Dur und Moll, [b.a.], „L'Europe” 1882, nr 917, s. 1.

58 Eingesandte Concert-Programme, [b.a.], ,Musikalisches Centerblatt” 1882, nr 18, s. 186.

59 Tamże, s. 186.

60 Eingesandte Concert-Programme, [b.a.], „Musikalisches Centerblatt” 1883, nr 4, s. 54.

61 Concerts Wieniawski, [b.a.], „L'Art Moderne” 1883, nr 5, s. 37.

62 Tamże. 
opus 37"63. Obok tej informacji zamieszczono krótką ocenę. Zdaniem krytyka „utwór to bardzo dobrze napisany, dostosowany do brzmienia fortepianu. Melodyczne zwroty mają pokrewieństwo z melancholijnymi marzeniami Chopina" ${ }^{4}$, co było w późniejszych latach wielokrotnie podkreślane przez innych publicystów.

W ostatnim dniu maja 1884 roku, na łamach czasopisma „Echo Muzyczne i Teatralne” pojawiła się pierwsza część artykułu autorstwa Jana Kleczyńskiego, będącego próbą przedstawienia biografii Józefa Wieniawskiego. Mówiąc ogólnie, krytyk stwierdził, że „jako kompozytor, okazał W. gruntowną znajomość form w sonacie na fortepian i skrzypce (op. 24), w koncercie, w sonacie z wiolonczellą"65.

Wątpliwości co do poziomu dorobku kompozytora u Kleczyńskiego pojawiają się po głębszej analizie. Zarzucił mu rozwlekłość, gdyż „zbyteczne wydłużenie formy czyni jednak Sonatę skrzypcową ciężką do grania, trwa ona, o ile pamiętamy, około trzech kwadransy"66. Opinie te z jego strony pojawiały się jeszcze kilkakrotnie w latach późniejszych, w odniesieniu do innych kompozycji. Jednocześnie „nierównie szczęśliwszym był W. w utworach stylu lżejszego, gdzie elegancya, dowcip, wdzięk przeważają" ${ }^{67}$, gdzie za przykład podał Valse de Concert op. 3 , który ,jest dotąd popularnym i przez wielu wirtuozów dotąd najchętniej grywanym"68. Po upływie ośmiu lat od przywołanej wcześniej wypowiedzi Kleczyński zwrócił uwagę na Polonaise op. 21 mający „wspaniały pierwszy temat - całość nie czyni jednak porywającego wrażenia; nieraz u W. robota późniejsza odbiera świeżość pierwotnemu pomysłowi"69. Wszystkie kompozycje Wieniawskiego do Polonaise op. 21 włącznie zaliczył Kleczyński do „wczesnych utworów”70. Drugą grupę utworów określił mianem późniejszych, spośród których „na uwagę zasługują: Ballada i 2-gi Walc koncertowy"71. Mówiąc to miał zapewne na myśli Balladę es-moll op. 31, bowiem wyłącznie tą umieścił w sporządzonym przez siebie katalogu. Obejmował on utwory od

63 Petite chronique, [b.a.], „L'Art Moderne” 1884, nr 4, s. 30.

64 Tamże, s. 30.

65 J. Kleczyński, Józef Wieniawski, „Echo Muzyczne i Teatralne” 1884, nr 36, s. 370.

66 Tamże.

67 Tamże.

68 Tamże, s. 371.

69 Tamże.

70 Tamże.

71 Tamże. 
Deux Idyles op. 1 do Six pièces romantiques op. 39. Kleczyński pierwszy spis kompozycji Wieniawskiego wzbogacił o dedykacje i wydawców poszczególnych utworów. Należy jednak zauważyć, że był on niekompletny, bowiem zabrakło funkcjonującej już w druku Kadencji do 3-go Koncertu fortepianowego op. 37 Beethovena.

W czerwcu 1884 roku pojawiła się informacja, że „Pan Józef Wieniawski kontynuuje bieg publikacji muzycznych, ukazujących pełnię talentu mistrza"72. Od tego momentu prasa, głównie francusko- i niemieckojęzyczna regularnie informowała o jego poczynaniach kompozytorskich. W połowie sierpnia „Le Guide Musical” zamieściło wzmiankę dotyczącą Six Piéces Romantiques op. 39. Dowiadujemy się, że „na koniec miesiąca Sześć romantycznych utworów op. 39 Józefa Wieniawskiego wydane zostały przez wydawnictwo braci Schott w postaci dwóch zeszytów, sprzedawanych po 30 franków każdy"73.

Niedługo później ukazał się również Mazourka de Concert op. 41. Był to dla Wieniawskiego bardzo intensywny czas nie tylko na polu kompozytorskim, bowiem wzorem poprzednich dwóch lat wznawiał „kurs fortepianowy prowadzony u siebie w domu przy Rue du Pepin 23. Kurs ten stał się niezbędnym dla naszej edukacji muzycznej" 74 . Stało się to jedną z motywacji do powstania zbioru. Każdy z kolejnych utworów w opus 39 zadedykował innej uczennicy. W październiku dowiadujemy się, że: „będąc płodnym kompozytorem, o wszechstronnych talentach, panujących nad swoja myślą i z łatwością ją wyrażającym, pan Józef Wieniawski wzbogacił repertuar pianistów serią eleganckich i pociągających dzieł"75.

Podkreślono jego błyskotliwość, szlachetność stylu i zdolność do improwizacji. Zbiór spotkał się jednak nie do końca z przychylnym odbiorem, bowiem „w Balladzie, która tworzy czwarty z jego romantycznych utworów w serii, ociera się o imitację, przed którą pragnęlibyśmy go ostrzec"76, natomiast Mazourka de Concert op. 41 określono mianem „wybitnej kompozycji, pełnej wigoru i zuchwałości, o pewnym i powściągliwym zarysie"77.

72 Les peintres belges au salon, [b.a.], „L'Art Moderne” 1884, nr 25, s. 205.

73 Nouvelles diverses, [b.a.], „Le Guide Musical” 1884, nr 34-35, s. 232.

74 Nouvelles diverses, [b.a.], „Le Guide Musical” 1884, nr 37, s. 243.

75 Nouvelles diverses, [b.a.], „Le Guide Musical” 1884, nr 43, s. 349.

76 Tamże, s. 349 .

77 Tamże. 
Krytyk podkreśla również umiejętność posługiwania się stylistyką charakterystyczną dla tańca narodowego: „słychać w jego harmonii nowe dźwięki pobrzękiwania ostróg; można sobie wyobrazić, w kołysaniu jego rytmu, wirowanie roztańczonych par, oszołomionych blond głów na pasiastych branderburskich piersiach"78.

W tym samym czasie na łamach polskiego czasopisma wypowiedział się anonimowy rodak Wieniawskiego. Jego zdaniem są to utwory „dobrze i starannie napisane"79. Wybrane z nich omówił zdawkowo: „Idylla najwdzięcznièj się rysuje, temat Ballady jest bardzo udany, a Evocation wydaje się być nieco napuszonym" 80 . Takie zestawienie wypowiedzi wskazuje jednocześnie na obiektywizm autora. Działalność koncertową i kompozytorską Wieniawskiego przerwała w tym momencie na krótko śmierć jego matki.

10 kwietnia 1885 roku Wieniawski zaprezentował dwa utwory wchodzące w skład wspomnianego wcześniej zbioru op. 39. Zdaniem Jana Kleczyńskiego „Jeu des fées ślicznie zostało odegrane”"1, jednak „Elégie orientale nie przemówiła do słuchaczy"82. Znacznie więcej uwagi Kleczyński poświęcił Koncertowi fortepianowemu g-moll op. 20, zaprezentowanemu na zakończenie tego występu. Jego „część I-sza, lubo trochę w salonowym patosie trzymana, jest wdzięczna i szlachetna"s3, natomiast odnośnie do pozostałych fragmentów miał mniej pochlebne zdanie, niemalże negując koncepcje utworu. Doszedł do wniosku, że „na dwie drugie, a zwłaszcza na Finał godzić się nie możemy, gdyż tkwi w nim jakaś staroświetczyzna stylu, która dziś jest tu anachronizmem"84. Oznacza to, że w opinii Kleczyńskiego zyskiwały na wartości dzieła z późniejszego okresu. W październiku czytelnicy tej samej gazety mogli przeczytać: „Józef Wieniawski wydał Trio z fortepianem (op. 40). Nie znamy go jeszcze" 85 , natomiast pod koniec listopada „ukończył genialną fantazję na dwa fortepiany, która zostanie zaprezentowana przez nie-

78 Petite chronique, [b.a.], „L'Art Moderne” 1884, nr 43, s. 349.

79 Nowości Muzyczne, [b.a.], „Echo Muzyczne i Teatralne” 1884, nr 56, s. 576.

8 o Tamże, s. 576.

81 J. Kleczyński, Koncert Józefa Wieniawskiego, „Echo Muzyczne, Teatralne i Artystyczne" 1885, nr 81, s. 158.

82 Tamże.

83 Tamże.

84 Tamże.

85 A. Urbański, Korespondencye Echa, „Echo Muzyczne, Teatralne i Artystyczne” 1885 , nr 110, s. 428. 
go i Pana Artura de Greef, podczas koncertu 19 grudnia" 86 . Podobną informację zamieściła holenderska "Caecilia"87, co świadczy o zainteresowaniu utworem: „Pan Józef Wieniawski ukończył właśnie Fantazje na dwa fortepiany, którą zaprezentuje wspólnie z Panem Arthurem de Greef, podczas koncertu, w dniu 19 grudnia w Le Grand Harmonie" 88 .

Podczas tego samego koncertu w części wokalnej wystąpiła Anna Gregoir, wykonując dwie pieśni Wieniawskiego: „Si vous n'avez rien à me dire no 2 i Il m'aimait tant no $4^{89}$ " wchodzące w skład opus 38 . Autor wypowiedzi powstrzymał się jednak od komentarza.

W Brukseli miejscem, które obok Le Grand Harmonie równie często odwiedzał Wieniawski, był Palais des Beaux-Arts, dając tam cykliczne koncerty, do udziału w których zapraszał zaprzyjaźnionych muzyków. Tam 17 lutego odbył się pierwszy z dwóch zaplanowanych, podczas którego miała miejsce prezentacja Tria fortepianowego op. 40. Uczestniczyli w niej: Jenő Hubay (skrzypce) i Joseph Jacob (wiolonczela). W recenzji dzieło zostało poddane szczegółowemu omówieniu:

\begin{abstract}
Wychwalamy Trio Pana Wieniawskiego, a zwłaszcza części 1, 2 i 4: pierwszą za nieco romantyczną brawurę, o brzmieniu przypominającym Chopina i Liszta; drugą za rozwinięcie niepozornego tematu, niosącego w sobie melancholię popularnej polskiej pieśni a czasami z elementami Griega; oraz czwartą, najbardziej podniosłą i porywającą, ale również pełną wspomnień, tym razem o Wagnerze ${ }^{90}$.
\end{abstract}

Z odmienną oceną spotkała się część trzecia - Scherzo, bowiem „brakowało w nim rozwinięcia, a kończyło się ze zbytnią gwałtownością" ${ }^{11}$, natomiast druga prezentacja utworu w Brukseli, wykonana w tym samym składzie odbyła się w dniu 2 marca. Dwa tygodnie później szczegółowa wypowiedź Jana Kleczyńskiego dotycząca kompozycji zamieszczona została na łamach polskojęzycznego czasopisma. Wypowiedział się w następujący sposób:

86 Province, [b.a.], „Le Guide Musical” 1885, nr 49, s. 351.

87 Nieuve uitgaven, [b.a.], „Caecilia. Algemeen Muzikaal Tijdschrift van Nederlanden” 1885 , nr 24, s. 327.

88 Tamże.

89 Zob. Petite chronique, [b.a.], „L'Art Moderne” 1886, nr 1, s. 7.

90 Petite chronique, [b.a.], „L'Art Moderne” 1886, nr 8, s. 61.

91 Tamże. 
Ten nowy utwór na fortepian, skrzypce i wiolonczellę wzięliśmy do ręki z prawdziwem zajęciem i wielkiem zaciekawieniem. Znając dotąd sonaty: na fortepian i skrzypce oraz fortepian i wiolonczellę tegoż autora, ceniliśmy w tych dziełach fakturę i plan, zarzucając pierwszej zbyteczną rozwlekłość, w drugiej uważaliśmy, że forma skupiona lepiej interesuje, zaś Andante nawet nie małym przemawia wdziękiem. W Trio spodziewaliśmy się odkryć nie mało przymiotów. Nadzieje te jednak prawie zupełnie zawiedzione zostały. Temata - oprócz pomysłu Scherza suche i niewdzięczne, a forma rozwleczona. Wszystko przeładowane sztucznym patosem. Przy starannem wykonaniu Adagio i Scherzo szczególniej mogą zrobić wrażenie. Dzieło całe wydaje się chybione ${ }^{92}$.

Spoglądając na przywołane opinie dostrzegamy jeden z przykładów wyraźnego rozdźwięku w postrzeganiu twórczości Wieniawskiego, przez krytyków polskich i zagranicznych. O ile prasa zagraniczna chwaliła Trio, jego przyjaciel z lat spędzonych w Warszawie uznał je za zupełnie nieprzemyślane i nieudane. Pochwalił jednak Scherzo, które skrytykował jego belgijski odpowiednik. Potwierdza to informacja z kwietnia 1886 roku, w której czytamy, że „bracia Schott opublikowali bardzo interesujące Trio na pianino, skrzypce i wiolonczelę Józefa Wieniawskiego"93, co utwierdza przekonanie o panującym rozdźwięku pomiędzy dwoma ośrodkami.

Drugą połowę 1886 roku zdominowały informacje o wspomnianej już Fantazji op. 42 na dwa fortepiany. Tym razem, jako pierwszy swój komentarz zamieścił Jan Kleczyński, wyrażając się w bardziej przychylnym tonie, zwracając uwagę na formę, przypominającą „wielkie preludium" 94 . Dodał, że w literaturze przeznaczonej na dwa fortepiany „nie tak znów niezmiernie bogatèj, dzieło to będzie cennèm jèj wzbogaceniem"95. Oznacza to, że w pewnym stopniu nie docenił innych kompozytorów polskich, tworzących równolegle $\mathrm{z}$ Wieniawskim dzieła na dwa fortepiany, które w liczbie nie ustępowały tym $z$ innych części Europy, szczególnie, gdy weźmie się pod uwagę takie nazwiska, jak Henryk Pachulski czy Maurycy Moszkowski.

92 J. Kleczyński, Nowości muzyczne, „Echo Muzyczne, Teatralne i Artystyczne” 1886, nr 128, s. 110.

93 Bibliographie musicale, [b.a.], „L'Art Moderne” 1886, nr 14, s. 110.

94 J. Kleczyński, Nowości muzyczne, „Echo Muzyczne, Teatralne i Artystyczne” 1886, nr 141, s. 240.

95 Tamże. 
Pod względem prezentacji własnych kompozycji obficie rozpoczął się rok 1887, kiedy Wieniawski przebywając w Paryżu przygotowywał się do koncertów w Sali Erarda. W trakcie trzech występów 31 stycznia oraz 7 i 14 lutego: „programy zawierać będą, pomiędzy dziełami z repertuaru klasycznego i współczesnego na pianino, następujące kompozycję Pana Wieniawskiego: Trio na pianino, skrzypce i wiolonczelę, Fantazje na dwa pianina, Utwory romantyczne na pianino solowe, Ekstaze i inne pieśni wokalne, a także Guillaume le Taciturne"96.

$\mathrm{W}$ prasie pominięte jednak zostały relacje z koncertów. Podczas gdy Wieniawski przygotowywał się do kolejnych występów, w Brukseli trwały prace nad wydaniem Fantaisie op. 42. Informacji tej towarzyszyła opinia:

Napisana jest $\mathrm{z}$ talentem, biegłym piórem, które radzi sobie z trudnościami polifonicznymi, zręcznie je prowadzi, pozostawiając każdemu instrumentowi mniej więcej równe samodzielne partie. Wykazuje kawaleryjską elegancję, a także rodzaj dandyzmu, który jest cechą własną dzieł Wieniawskiego ${ }^{97}$.

Również w późniejszych latach, podczas kolejnych wykonań, głównie z Arthurem de Greefem, utwór spotykał się z przychylnymi recenzjami. W pierwszej połowie 1887 roku w repertuarze koncertowym Wieniawskiego stałe miejsce zajmowało jego Trio fortepianowe op. 40, jeszcze w tym półroczu zaprezentowane w Paryżu i Londynie. Otóż 29 marca „W Sali Erarda grał Trio op. 40 własnèj kompozycyi z panami Remy i Deslertem” 98 . W maju natomiast „Le Figaro” poinformowało, że „Pan Józef Wieniawski wkrótce udaje się do Londynu, gdzie wystąpi prezentując własne kompozycje" ${ }^{99}$. W stolicy Wielkiej Brytanii pianista wystąpił dając cztery koncerty, w tym jeden z nich w czwartek 16 czerwca w St. James's Hall. Zdaniem lokalnej prasy był to bardzo interesujący występ, który przyciągnął rzeszę miejscowych melomanów. Wówczas „wspólnie z Panią Norman-Néruda i Panem Patti zaprezentował Trio op. 40 własnej kompozycji"100, jednak więcej szczegółów na ten temat zamieściło „Le Guide Musical”. Dowiadujemy

96 Petite chronique, [b.a.], „L'Art Moderne” 1887, nr 2, s. 15.

97 Petite chronique, [b.a.], „L'Art Moderne” 1887, nr 13, s. 102.

98 Nowości Muzyczne, „Echo Muzyczne, Teatralne i Artystyczne” 1887, nr 183, s. 177.

99 Petites Nouvelles, [b.a.], „Le Figaro” 1887, nr 140, s. 3.

100 „Ilustrated London News” [b.a.], 1887, nr 2514, s. 714. 
się, że „usłyszeliśmy Trio op. 4o kompozycji Pana Wieniawskiego, w którym szczególnie andante i finale były oklaskiwane"101, co świadczy o popularności tego utworu.

Pod koniec 1887 roku pojawiło się kilka odniesień do jego twórczości. „Echo Muzyczne, Teatralne i Artystyczne” zwróciło uwagę na przygotowywany przez kompozytora cykl etiud:

\footnotetext{
Józef Wieniawski układa zbiór etiudów stylu i techniki (virtuosite) we wszystkich tonacjach majorowych i minorowych. Całość zbioru, przeznaczonego dla osób wysoko posuniętych muzykalnie, obejmie 24 utworów. Każdy z nich ma być dedykowany jednemu ze słynnych pianistów, do którego natury talentu i indywidualności artystycznej się pośrednio odnosi ${ }^{102}$.
}

Po występach w Wielkiej Brytanii pianista udał się w dalszą podróż do Niderlandów. W grudniu pojawiła się informacja, że „Marcela Sembrich i Józef Wieniawski właśnie zakończyli trasę koncertową w Holandii"103, co stwarzało kolejną możliwość do prezentacji własnego dorobku kompozytorskiego. Krytyk dodaje, że „dwoje wielkich artystów wykonało piękny program. Extase Wieniawskiego, która była wszędzie przyjmowana owacjami adresowanymi do obojga artystów"104. W polskiej prasie natomiast znalazła się wzmianka o tym, że: „szczególnie pieśń Wieniawskiego Ekstaza była wyróżnioną zjednywając gorące oklaski autorowi i wykonawczyni" ${ }^{105}$. W sobotę 27 grudnia w Liège miał miejsce kolejny koncert symfoniczny z udziałem Józefa Wieniawskiego. W jego programie „obok Symfonii $H$-dur Haydna znalazła się Guillaume le Taciturne Józefa Wieniawskiego"106, kiedy zaprezentował się w roli dyrygenta.

Pierwsza połowa 1888 roku nie stworzyła zbyt wielu okazji do prezentacji własnej twórczości, dlatego też wątek został przemilczany w prasie. W kwietniu na łamach czasopisma „Kłosy” pojawiła się krótka notatka sporządzona przez anonimowego autora:

101 Nouvelles diverses, [b.a.], „Le Guide Musical” 1887, nr 26-27.

102 Nowości Muzyczne, [b.a.], „Echo Muzyczne, Teatralne i Artystyczne” 1887, nr 218,

s. 571.

103 Petites Nouvelles, [b.a.], „Le Figaro” 1887, nr 349, s. 3.

104 Tamże.

105 Nowości Muzyczne, [b.a.], „Echo Muzyczne, Teatralne i Artystyczne” 1887, nr 222, s. 618 .

106 Nouvelles diverses, [b.a.], „Le Guide Musical” 1887, nr 52, s. 342. 
Pan Wieniawski z większych dzieł napisał: koncert fortepianowy, Sonatę na fortepian i skrzypce, sonatę na fortepian i wiolonczellę, kwartet smyczkowy, trio fortepianowe i uwerturę koncertową. Z kompozycyi jego salonowych największego dostąpiły uznania: walc koncertowy, romans, mazurki, etiudy, a w ostatnich czasach śliczna pieśń: Extaza ${ }^{107}$.

Krytyk zwrócił uwagę na jego zdaniem prawdopodobnie najbardziej reprezentatywne utwory, nie poddając ich jednak bardziej szczegółowej ocenie. Podobna informacja pojawiła się dopiero w listopadzie. Dotyczyła jednego z organizowanych corocznie przez Wieniawskiego koncertów w Sali Erarda, który miał miejsce 16 listopada. Ze wzmianki zamieszczonej na łamach „L’Art Moderne” wynika, że artysta wykonał Fantazję op. 42 na dwa fortepiany, podczas której towarzyszyła mu Louisa Merck ${ }^{108}$ - jego uczennica.

Dopiero w pierwszym kwartale 1891 roku pojawiła się w polskiej prasie informacja o ukończeniu długo wyczekiwanego cyklu etiud we wszystkich tonacjach. Poinformował o tym Jan Kleczyński:

Józef Wieniawski. 24 „Etudes de mécanisme et de style pour le piano dans tous les tons majeurs et mineurs en 4 cahiers". Wydawnictwa tego trzy zeszyty leżą przed nami. Wyznajemy, że wyczytawszy z półtora roku temu w „Guide musicale" entuzyastyczny artykuł o tych etiudach, nazywający je "pomnikiem muzycznym” spodziewaliśmy się po nich czegoś więcej. Jest to szereg utworów dobrze napisanych, świadczących, że autor zna fakturę muzyczną i z tego względu sprawiający w ogóle przyjemne wrażenie. Są one jednak, jak cała prawie twórczość Wieniawskiego, nacechowane stylem dawniejszej epoki, i pod tym mianowicie względem nie są w stanie głębiej zainteresować. Pomysły ich są zresztą zwyczajne, a trudność i stopień efektywności średnie. Niektóre tylko wyróżniają się, jak 4-ta, 7-ma, początek 14-stej (fuga) ${ }^{109}$.

Podobnie, jak poprzednio, w odniesieniu do innych kompozycji także i tym razem napotykamy surową ocenę z jego strony. Pod koniec maja na łamach brytyjskiego czasopisma pojawiła się informacja o koncercie Ignacego Jana Paderewskiego w St. James's Hall, zaplanowanym

107 Ruch Muzyczny, [b.a.], „Kłosy” 1888, nr 119o, s. 225.

108 Petite chronique, [b.a.], w: Zob. „L'Art Moderne” 1888, nr 47, s. 374.

109 J. Kleczyński, Nowości Muzyczne, „Echo Muzyczne, Teatralne i Artystyczne” 1891, nr 390, s. 166. 
na dzień 2 czerwca. Wówczas wziął w nim udział również Wieniawski, dyrygując swoją Overture Dramatique „Guillaume de Taciturne” 110 i odnosząc sukces. Nie był to jedyny występ Wieniawskiego w Londynie, bowiem na 26 czerwca zaplanowano kolejny koncert, podczas którego zaprezentował się jako solista i kameralista:

\footnotetext{
Artyście towarzyszyć będzie Pan Joseph Hollman, z którym wspólnie wykona Sonate wiolonczelowa op. 26 własnej kompozycji. Ponad to Pan Wieniawski wykona: 3me Polonaise op. 27, Romances sans Paroles, Etude de Concert op. 33, Sur l'Océan. Wspólnie z Panem Paderewskim artysta odegra własną Fantaisie op. 42 na dwa fortepiany ${ }^{111}$.
}

Była to już szósta wizyta pianisty w Wielkiej Brytanii, jednak tym razem program poszczególnych koncertów pierwszy raz zdominowała jego twórczość. Koniec 1891 roku, wzorem kilku poprzednich lat upłynął pod znakiem koncertów w Le Grand Harmonie. 12 listopada nie tylko kolejny raz wykonał z orkiestrą swój Koncert fortepianowy, ale po raz pierwszy zamieszczono informację o tym, że „Panie Matthysens i De Gre pięć zagrały duetów opus 47 w sopranie i alcie kompozycji Wieniawskiego"112, co należy uznać za premierowe wykonanie.

Podobnie jak w latach poprzednich, nastała przerwa w prezentacji własnego dorobku, trwająca do pierwszej połowy 1893 roku. Dowiadujemy się, że „w Sali Erarda, w dniu 18-go maja zostanie wykonana jego Suite Romantique, którą będzie dyrygował sam kompozytor"113, natomiast tydzień później na łamach tej samej gazety przedstawiona została dokładnie budowa utworu: „Suite Romantique Pana Józefa Wieniawskiego, którą będzie dyrygował podczas koncertu w najbliższy czwartek składa się z czterech części: Evocation, Scherzo, Idylle i Mazurka villageoise ${ }^{14}$.

Pod koniec listopada dowiadujemy się, że „po dłuższej przerwie Pan Józef Wieniawski odwiedził Lipsk"115, gdzie wzorem lat poprzednich zaprezentował się w miejscowym Gewandhausie. 8 grudnia „Pan Wieniawski wystąpił z orkiestrą. W programie znalazł się jego dobrze

110 Zob. „Morning Post” [b.a.] 1891, nr 37.112, s. 1.

111 „The st. James's Gazette” [b.a.] 1891, nr 3443, s. 1.

112 Dur und Moll, [b.a.], „Signale für die Musikalische Welt” 1891, nr 72, s. 140.

113 Petites Nouvelles, [b.a.], „Le Figaro” 1893, nr 101, s. 3.

114 Petites Nouvelles, [b.a.], „Le Figaro” 1893, nr 135, s. 5.

115 Dur und Moll, [b.a.], „Signale für die Musikalische Welt” 1893, nr 67, s. 1059. 
nam już znany Koncert fortepianowy g-moll op. 20"116. W tym samym mieście zaprezentował się w pod koniec lutego 1895 roku. Wówczas: „pianista i kompozytor, mieszkający obecnie w Brukseli, również wykazał pełnię swoich umiejętności. Realizując partię fortepianu w swoim Trio op. 40, z udziałem Panów Brill'a i Will'a wywołał burzę oklasków"117. Krytyk w swojej wypowiedzi zawarł również następującą ocenę: „utwór ten wydaje się łączyć w sobie spójność formy z lekkością i równym traktowaniem trzech instrumentów. Świadczy to o jego kunszcie i dojrzałości w dwóch tych dziedzinach - pianisty i kompozytora" ${ }^{118}$.

W podobnym duchu odniosła się prasa francuskojęzyczna: „dzieło nikogo nie zaskoczyło ani nowością pomysłów, ani siłą emocji, ale rozwój formy i szlachetność nadały mu prawdziwą wartość"119. Koncerty w Lipsku były jednym z etapów tournée po Niemczech, o czym przypomniało "L’Art Moderne”. Autor wzmianki nawiązał do koncertów w Berlinie, w których Wieniawski wziął udział prezentując własną twórczość symfoniczną. Jak czytamy: „w Berlinie Pan Wieniawski wystąpił w Concerthaus, $\mathrm{z}$ dwoma koncertami z orkiestrą. W programie zawarł trzy ważne dzieła jego własnej kompozycji: jego Symphonię D-dur, Suite romantyczna na orkiestrę oraz Koncert na pianino z akompaniamentem orkiestry” ${ }^{120}$. Przyniosło mu to kolejny sukces w stolicy Niemiec: „Pan Wieniawski, który sam dyrygował podczas dwóch pierwszych utworów i który wziął udział w wykonaniu koncertu, zyskał gorący aplauz i był kilkukrotnie wywoływany na scenę"121. Maj 1895 roku natomiast spędził w Paryżu, gdzie wystąpił dwukrotnie w Sali Pleyela. Podczas drugiego koncertu, 28 maja „wykonana została, wspólnie z Panem G. Remmy własna Sonata skrzypcowa"122, odnośnie do utworu wypowiedział się jeden z krytyków: ,jest to utwór improwizowany, który przekonał nas do prac bardziej swobodnych"123. Jako uzupełnienie do programu pianista spośród własnych kompozycji wykonał: „Polonez Triumfalny, Etiudę oktawową i Jeux de fée, które już słyszeliśmy wcześniej”"124.

116 Tamże.

117 Dur und Moll, [b.a.], „Signale für die Musikalische Welt” 1895, nr 17, s. 258.

118 Tamże.

119 Nouvelles diverses, [b.a.], „Le Guide Musical” 1895, nr 15, s. 355.

120 Petite chronique, [b.a.], „L'Art Moderne” 1895, nr 16, s. 125.

121 Tamże.

122 Soirées et concerts, [b.a.], „Le Ménestrel” 1895, nr 19, s. 152.

123 Nouvelles diverses, [b.a.], „Le Guide Musical” 1895, $\mathrm{nr}$ 23-24, s. 519.

124 Tamże. 
W pierwszej połowie 1896 roku artysta wystąpił w Warszawie, do której „wraz z Władysławem Żeleńskim przybył 15-go kwietnia”"125. Po kilku miesiącach, które upłynęły od koncertu w Paryżu zaprezentował swoją twórczość. Wówczas 19 kwietnia, w Salach Redutowych artysta wystąpił z orkiestrą, wykonując dwa utwory: „części pierwszej Koncertu fortepianowego g-minor J. Wieniawski przypomina się jako wybitny wirtuoz umiejący uderzyć i w stronę twórczości"126.

Ponadto zabrzmiała Suita romantyczna, co do której wykonania pojawił się następujący komentarz:

\footnotetext{
Posłuchaj takiego Mazura sielankowego z orkiestrowej Suity romantycznej, a $\mathrm{z}$ tego dzieła drgającego całą pełnią rytmiki, dowcipu i zdrowego humoru, przekonasz się, że jest on właściwością, jest on tworem gleby naszej, którą wzbogacił nauką, doświadczeniem, postępem artysty na zdobytych laurach nie odpoczywającego, lecz wytrwale na przód zmierzającego. Istotnie, zarówno Mazur, jak i Evocation świadczą o sile talentu prawdziwej. Kiedy nasłyszymy to dzieło w całości? ${ }^{127}$.
}

Pomimo tak przychylnych recenzji, nie doszło do ponownego wykonania utworu w Warszawie. Był to jednocześnie ostatni koncert symfoniczny, z jakim Wieniawski wystąpił na terenie Królestwa Polskiego. Ponownie odwiedził Warszawę w 1897 roku, gdzie 11 marca wziął udział w koncercie kameralnym. Lubelski wiolonczelista, Michał Biernacki, zauważył, że „poznaliśmy Trio jego, Fantazyę na dwa fortepiany i 3 duety wokalne" ${ }^{\prime 28}$. Dokonał również krótkiej charakterystyki:

Trio brzmi przeto wybornie, a zwłaszcza pod palcami autora, Barcewicza i Cinka. W fantazyi starczy Wieniawskiemu rzeczywiście fantazyi i pomysłów na to, aby uniknąć szablonu, czyli waryacyi nieuchronnych w dotychczasowych kompozycyach na 2 fortepiany, ażeby swój romantyczny motyw główny - delikatny przedstawić zajmująco w rozwoju logicznym, wypełnić niemi ramy utworu i ubarwić efektami wirtuozowskiemi. Koncertant oraz doskonała partnerka jego - p. Jankowska - wywiązywali się świetnie z niełatwego, acz nie niewdzięcznego zadania. Od stylu patetycznego, jaki w utwo-

125 „Kurier Warszawski” [b.a.] 1896, nr 105, s. 3. 126 „Kurier Warszawski” [b.a.] 1896, nr 109, s. 4. 127 Tamże.

128 M. Biernacki, Ruch Muzyczny, „Echo Muzyczne, Teatralne i Artystyczne” 1897, nr 11. 
rach Wieniawskiego przeważa odbiegają trzy pieśni dwugłosowe: Zbudź się, Kalif Omar, Pieśń majowa, które z liczby 6-ciu wydanych wykonały artystycznie p. Róża Rapacka (lekki, a melodyczny sopran) i p. Vieweger (alt piękny i dźwięczny). Słowa Goethego i Bodenstedta ilustruje wdzięczna melodya sopranu postępującego zazwyczaj razem $z$ altem, prócz w pieśni drugiej, najgłębszej, gdzie każdy z głosów występuje z osobna. Pieśń trzecia o mniejszym zakroju (identyczne strofy i ritornella) odczuwać daje prawdziwie „tchnienie wiosenne", to też podobała się najbardziej i była powtarzaną. Wszystkie zaś duety podnosi wykwintna partya fortepianowa, to głosom towarzysząca, to samodzielnie mająca coś do powiedzenia ${ }^{129}$.

Michał Biernacki, będący członkiem kapeli działającej przy Katedrze w Lublinie, a jednocześnie związany z Warszawskim Towarzystwem Muzycznym przychylnie odniósł się do zaprezentowanej twórczości Wieniawskiego, stając w opozycji do Jana Kleczyńskiego. Kilka tygodni później pianista zaprezentował się trzykrotnie w paryskiej Sali Pleyela: 8, 15 i 22 kwietnia ${ }^{130}$, natomiast w zapowiedzi czytamy, że „podczas ostatniego występu Pan Wieniawski zaprezentuje własne kompozycje wokalne i instrumentalne"131, a zatem obejmujące podobny program jak przedstawiony w Warszawie. Nie była to jednak precyzyjna informacja. Jak dowiadujemy się później, w dniu 8 kwietnia: „pomiędzy dziełami, które zostaną zaprezentowane podczas koncertu, znajduje się Symfonia op. 49 Pana Wieniawskiego; zostanie ona wykonana pod batutą autora"132. Zabrakło jednak sprawozdania poświęconego ostatniemu $\mathrm{z}$ koncertów.

W maju 1898 roku renomowane czasopismo muzyczne poinformowało o nowopowstałym cyklu, opatrzonym numerem opusowym 51, obejmującym cztery kompozycje: Impromptu, Etiude, Tristesse, Valse. Zdaniem krytyka: „Impromptu utrzymane jest w delikatnym nastroju, będąc w muzycznej sensie i wybrane w harmonii. Bardzo szczęśliwie kontrastuje z kontemplacyjnym, skutecznie wyodrębnionym pierwszym motywem niskiego, bogatego w figury"133. Dalej dowiadujemy się, że: jako intermezzo bardzo dobrze sprawdziła się następująca po tym Etiuda z pobudzającą, poruszającą szesnastą

129 Tamże.

130 Courrier de la semaine, [b.a.], „Le Monde Artiste” 1897, nr 13, s. 206.

131 Tamże.

132 Petite chronique, [b.a.], „L'Art Moderne” 1897, nr 13, s. 103.

133 Dur und Moll, [b.a.], „Signale für die Musikalische Welt” 1897, nr 33, s. 513. 
częścią, rodzaj perpetuum mobile. W duchu kompozytora w najżywszym czasie i wykonany luźnymi, giętkimi palcami, pozwolił wyrazić mistrzowską sztukę"134.

W podobnym tonie krytyk wypowiedział się na temat dwóch pozostałych utworów ${ }^{135}$. Podobna informacja pojawiła się w listopadzie na łamach prasy francuskiej. Autor wypowiedzi każdą z kompozycji poddał dość szczegółowej analizie. Całość natomiast zwieńczył podsumowaniem:

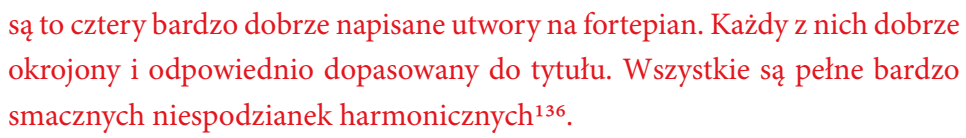

Jeszcze pod koniec 1898 roku, w Le Grand Harmonie brukselska publiczność wysłuchała Sonaty wiolonczelowej op. 26 „wykonanej przez Panów Józefa Hollmana i Józefa Wieniawskiego"137 - będących jednym z najpopularniejszych duetów ówczesnej sceny w Brukseli.

W maju 1899 roku kolejny raz odwiedził Londyn, dając tam cykl koncertów w St. James’s Hall. Występ z dnia 11 maja składał się z dwóch części: solowej i kameralnej. Jak dowiadujemy się: „w koncercie przyjęli udział: Theodore Werner, Alfred Hobday, Haydn Inwards i W.F. Whitehouse. Artyści zaprezentują Kwartet smyczkowy op. 32 Józefa Wieniawskiego"138. Dzieło spotkało się z następującą oceną ze strony brytyjskich krytyków:

\footnotetext{
To atrakcyjne dzieło składa się z pierwszej części o przeważnie silnym charakterze i silnej ekspresji. Potem następuje Andante cantabile, absolutnie zachwycająca część, zawierająca wiele autentycznych melodyjnych i pełnych gracji momentów. Po pomysłowym Scherzo następuje żywy i przyjemny finał, który doprowadza dzieło do imponującego zakończenia ${ }^{139}$.
}

Była to pierwsza tak szczegółowa ocena Kwartetu smyczkowego op. 32. We wrześniu poinformowano o koncercie w Hadze, podczas którego "usłyszymy Uwerturę Pana Józefa Wieniawskiego" ${ }^{140}$, jednak nie podano

134 Tamże.

135 Zob. Tamże, s. 513-514.

136 Chronique étrangère, [b.a.], „Revue Musicale Sainte Cécile” 1898, nr 3, s. 21.

137 Nouvelles diverses, [b.a.], „Le Guide Musical” 1898, nr 48, s. 906.

138 ,The Daily Telegraph” [b.a.] 1899, nr 13.730, s. 1.

139 Tamże.

140 Nouvelles diverses, [b.a.], „Le Guide Musical” 1899, nr 37, s. 661 
bardziej precyzyjnych informacji. Jeszcze pod koniec tego roku pianista wystąpił z cyklem koncertów w Maison d'Art, gdzie 14 listopada wspólnie z J. Hollmanem wykonał własną Sonatę wiolonczelową op. 26: „Ten pełen uroku utwór, którego żywe tematy odznaczają się oryginalnością są rozwijane $\mathrm{z}$ humorem i w których wiedza jego ujawnia się $\mathrm{w}$ każdym kolejnym takcie to dzieło pełne podziwu spotkało się $\mathrm{z}$ aplauzem po każdej jego części"141. Autor wypowiedzi ponownie zaprezentował odmienne zdanie, niż przywołany wcześniej Jan Kleczyński.

Kilka miesięcy później, a dokładnie 5 kwietnia 1900 roku w Le Grand Harmonie Wieniawski kolejny raz dał się usłyszeć jako twórca literatury symfonicznej. Przez cały czas prowadził intensywną działalność koncertową, jednak dopiero w 1903 roku pojawiły się kolejne informacje dotyczące jego kompozycji. Na początku lutego „Le Guide Musical" poinformowało o koncercie w Le Grand Harmonie. W repertuarze znalazły się utwory Beethovena i Chopina, a „bardzo doceniono dwie Jego kompozycje: Reverie i Romance no. $4^{\text {"142. }} \mathrm{Z}$ biegiem czasu Wieniawski prowadził równie intensywną działalność koncertową, o wiele rzadziej prezentując własne utwory.

Taka sytuacja miała miejsce we czwartek, 5 maja 1904 roku w Sali Pleyela, gdzie „podczas drugiego seansu Pan Wieniawski zaprezentuje wyłącznie własne kompozycje: Polonaise triomphale, Valse-caprice, Sonate pour le piano i inne"143. Dopiero w 1908 roku miał miejsce koncert symfoniczny z udziałem Wieniawskiego, będący jednym z jego ostatnich. Już w styczniu padła zapowiedź koncertu w Berlinie. Tam 9 kwietnia „w programie znajdą się: Symfonia D-dur op. 49 i Koncert fortepianowy g-moll op. 20 skomponowane przez niego samego"144. Kilka tygodni wcześniej z tym samym programem Wieniawski wystąpił w Le Grand Harmonie. Wówczas 19 marca „Pan Wieniawski pokierował orkiestrą, która wykonała jego Symfonię op. 40 i Koncert fortepianowy op. 20 "145, jednak prasa nie podała większej ilości szczegółów.

W 1908 roku pojawiły się dość szczegółowe analizy poświęcone wybranym kompozycjom. Bez wątpienia świadczy to o większym zainteresowaniu jego twórczością. W grudniu „Der Klavier-Lehrer”

141 Nouvelles diverses, [b.a.], „Le Guide Musical” 1899, nr 45, s. 849. 142 Nouvelles diverses, [b.a.], „Le Guide Musical” 1903, nr 6, s. 125. 143 Petites Nouvelles, [b.a.], „Le Figaro” 1904, nr 100, s. 4. 144 Soirées et concerts, [b.a.], „Le Ménestrel” 1908, $\mathrm{nr}$ 2, s. 13. 145 Soirées et concerts, [b.a.], „Le Ménestrel” 1908, nr 11, s. 87. 
poinformowało, że „Józef Wieniawski ponownie skorygował i opublikował jedno ze swoich dzieł z młodości - Sonate fortepianowa $h$-moll op. 22"146, natomiast podsumowując dość obszerną analizę autor doszedł do następujących wniosków:

\footnotetext{
Nie ulega wątpliwości, że zmiana czasu i smaku również przyczynia się do tego, że Sonata h-moll Wieniawskiego wydaje się nam dziś tak wyblakła i niewielka. Łatwo przyznać, że jej wrażenia z delikatnego wykładu, wciąż oferuje bardzo przyzwoitą, lekką muzykę. Sądząc z tego punktu widzenia, zasługuje na rekomendację ${ }^{147}$.
}

Twórczość Wieniawskiego z biegiem czasu przechodziła przeobrażenia w zakresie stylu i formy. Zostały one dostrzeżone przez kolejnego z niemieckich krytyków, który na łamach „Musikastetische Betrachtungen" dokonał omówienia wybranych kompozycji (Valse de concert op. 3, Berceuse op. 14 no. 2, Polonaise op. 27, Ballade op. 31, Etiude de concert op. 33, Etiude de concert op. 36), pochodzących z różnych okresów działalności ${ }^{148}$. W połowie roku pojawiła się również kolejna opinia dotycząca Sonaty fortepianowej op. 22. Jak zauważymy, wypowiedź ta zabrzmiała w odmiennym tonie niż wyżej zaprezentowana:

Forma sonaty nie wydaje mi się być najmocniejszą stroną tego kompozytora. W Allegro con brio dwa zdania skrajne są mocne i odważne, jednak środek niezbyt wyrafinowany. Architektura całości na niskim poziomie. Pod względem formalnym autor całkowicie zawodzi ${ }^{149}$.

Podobne zarzuty dotyczące kwestii formalnych padały już wcześniej ze strony Kleczyńskiego, odnoszącego się do Tria i Sonaty wiolonczelowej. Krytyka nie zniechęcała jednak Wieniawskiego do prowadzenia dalszej działalności kompozytorskiej. W połowie marca udał się po długiej przerwie do Lipska, gdzie wystąpił w dniu urodzin Johanna Sebastiana Bacha. Dowiadujemy się, że „Kunszt kompozytorski Pan Wieniawski udowodnił poprzez utwory, które wykonał: Etude de concert G-dur op. 33,

146 Joseph Wieniawski, [b.a.], „Der Klavier-Lehrer” 1908, nr 24, s. 9. 147 Tamże, s. 10.

148 Zob. N., Joseph Wieniawski, „Musikastetische Betrachtungen” 1909, nr 4, s. 233-235. 149 A. Leitzmann, Joseph Wieniawski Sonate pour Piano op. 22, „Die Musik” 1909, nr 4, s. 235. 
Barcarolle B-dur op. 29 i Valse caprice A-dur op. 46. Sonata h-moll"150, co spotkało się z podobnymi zarzutami, jak zawarte w poprzedniej wypowiedzi. Tym razem dowiadujemy się, że Sonata $h$-moll „nie jest to oryginalnie potraktowana forma, ale zbiór pasaży i figuracji znajdujących się zwłaszcza w pierwszej części nawiązującej do Schuberta"151. Być może sugerowało to ograniczenie się do trzyczęściowej struktury kompozycji. Pod koniec roku Wieniawski, wzorem lat poprzednich, rozpoczął cykl koncertów w Le Grand Harmonie. Pierwszy z nich odbył się w niedzielę 10 listopada, kiedy to „Panie: Couveiller i Kalker - uczennice Pana Flamenta odśpiewały przyjemnie dwugłosowe pieśni Pana Józefa Wieniawskiego" ${ }^{152}$. Cykl duetów op. 47 stanowił zwieńczenie liryki wokalnej Józefa Wieniawskiego. Kontynuacja tego cyklu miała miejsce w salonie muzycznym: Nouvelle Salle przy Rue Ernest Allard 11 w Brukseli. Zgodnie z zapowiedzią „w programie znajdą się: Kwartet smyczkowy Brahmsa i Kwartet smyczkowy Józefa Wieniawskiego (pierwsze wykonanie)"153. Ponownie podczas koncertu w dniu 11 maja wykonany został utwór poddany rewizji, dotyczącej głównie faktury i warstwy tonalnej. Wieniawski usunął również Scherzo, co sprawiło, że kompozycja przybrała strukturę trzyczęściową. Tym razem jednak „szczególną euforię wzbudziła jednak Sonata fortepianowa h-moll op. 22"154.

Drugi koncert odbył się 31 maja. Wieniawski zaprezentował się w gronie przyjaciół głównie jako kameralista, wykonując również kilka ustępów solowych. Swoje refleksje dotyczące koncertu na łamach francuskiego czasopisma zamieścił Charles Malherbe. W odniesieniu do muzyki kameralnej krytyk stwierdził, że „kompozycje, które zaprezentował: Sonata h-moll op. 22, Ballada. op. 31, 2-ga Etiuda koncertowa op. 33, to utwory, które świadczą o niezwykłej wrażliwości, zadziwiającym rozkwicie pomysłów oraz nienagannej harmonii”"155, co podkreśla poszczególne walory kompozytora. Ocenie poddana również została twórczość kameralna - oceniona w podobnym tonie:

Zaprezentował Pan Wieniawski: Kwartet smyczkowy op. 32, trio fortepianowe op. 40 i Sonate wiolonczelowa op. 26. Kwartet doczekał się znakomitej,

150 Leipzig, [b.a.], „Musikalisches Wochenblatt” 1910, nr 13, s. 7. 151 Tamże.

152 Nouvelles diverses, [b.a.], „Le Guide Musical” 1910, nr 46, s. 740.

153 Nouvelles diverses, [b.a.], „Le Guide Musical” 1911, nr 7, s. 134.

154 Nouvelles diverses, [b.a.], „Le Guide Musical” 1911, nr 22-23, s. 415.

155 Paris et départements, [b.a.], „Le Ménestrel” 1911, nr 23, s. 182. 
pełnej wdzięku interpretacji w wykonaniu Panów: André le Mayera i Césara Espéjo (skrzypce), Charlesa Meyeux’a (altówka) i Andre Bernaldel’a (wiolonczela). Sonata wiolonczelowa dzięki Panu Hollmanowi okazała się najbardziej efektownym punktem programu. Trio może uchodzić za cud, dzieło jedyne w swoim rodzaju ${ }^{156}$.

Informacja utrzymana w podobnym tonie pojawiła się na łamach „Le Guide Musical”157. Jednocześnie była to ostatnia relacja z koncertu Józefa Wieniawskiego, jaka pojawiła się w prasie. Artysta wychodząc na scenę, prawdopodobnie nie wiedział, że już tego więcej nie zrobi. Zrealizował swój testament, prezentując jedne z najbardziej reprezentatywnych utworów ze swojego dorobku kompozytorskiego.

Jak wspomniano we wstępie, osoba i twórczość Józefa Wieniawskiego nie doczekały się dotychczas współczesnego omówienia. Za życia należał jednak do grona polskich twórców, cieszących się dużą popularnością w najbardziej prestiżowych ośrodkach kulturalnych ówczesnej Europy. Świadczą o tym liczne informacje pochodzące z prasy polskojęzycznej, jak i zagranicznej, przebadanej na potrzeby niniejszego opracowania. W dużej mierze ukazujące się informacje dotyczyły nie tylko sprawozdań z koncertów, bądź powiadomienia o kolejnych. Równie intensywnie wnikliwej analizie i krytycznej ocenie poddawano dorobek kompozytorski Wieniawskiego, prezentowany regularnie na estradach. Na podstawie przeprowadzonej analizy źródeł należy stwierdzić, że wśród polskich i zagranicznych krytyków spuścizna autorstwa brata słynnego skrzypka cieszyła się dużym zainteresowaniem, będąc jednocześnie odbieraną w różnoraki sposób.

156 Tamże.

157 Zob. Salle Pleyel, [b.a.], „Le Guide Musical” 1911, nr 26-27, s. 456. 


\section{Bibliografia}

\section{Opracowania}

Delcroix L., Joseph Wieniawski, J.-B. Katto, Bruxelles 1908.

Rzepecki K., Józef Wieniawski (1837-1912) - epoka, człowiek i dzieło. Studium historyczno-muzykologiczne, Lublin 2019.

Wieniawski J., Cadenza pour le zme Concerto pour le Piano de Beethoven, Stanley Lucas, London 1878.

\section{Źródła prasowe}

Bibliographie musicale, [b.a.], „L'Art Moderne” 1886, nr 14.

Biernacki M., Ruch Muzyczny, „Echo Muzyczne, Teatralne i Artystyczne” 1897, nr 11.

Botte A., Koncert Józefa Wieniawskiego, „Revue Gazette Musicale de Paris" 1860, nr 52.

Bylicki F., Ze sceny koncertowej, „Gazeta Lwowska” 1881, nr 13.

Nieuve uitgaven, [b.a.], „Caecilia. Algemeen Muzikaal Tijdschrift van Nederlanden" 1885, nr 24.

Chronique étrangère, [b.a.], „Revue Gazette Musicale de Paris” 1857, nr 9.

Chronique étrangère, „Revue Gazette Musicale de Paris” 1860, nr 19.

Chronique étrangère, „Revue Musicale Sainte Cécile” 1898, nr 3.

Concerts Wieniawski, [b.a.], „L'Art Moderne” 1883, nr 5.

Courrier de la semaine, [b.a.], „Le Monde Artiste” 1897, nr 13.

Doroszeniko J., Wieści z kijowskich koncertów, „Ruch Muzyczny” 1859, nr 12.

Dur und Moll, [b.a.], „Signale für die Musikalische Welt” 1861, nr 38. Dur und Moll, [b.a.], „Signale für die Musikalische Welt” 1863, nr 18. Dur und Moll, [b.a.], „Signale für die Musikalische Welt” 1863, nr 42 Dur und Moll, [b.a.], „Signale für die Musikalische Welt” 1891, nr 72. Dur und Moll, [b.a.], „Signale für die Musikalische Welt” 1893, nr 67. Dur und Moll, [b.a.], „Signale für die Musikalische Welt” 1895, nr 17. Dur und Moll, [b.a.], „Signale für die Musikalische Welt” 1897, nr 33. Eingesandte Concert-Programme, [b.a.], „Musikalisches Centerblatt” $1882, \mathrm{nr} 18$. 
Eingesandte Concert-Programme, [b.a.], „Musikalisches Centerblatt” $1883, \mathrm{nr} 4$.

E.K., Przegląd kompozycyj, „, Ruch Muzyczny” 1857, nr 7.

"Ilustrated London News” [b.a.] 1887, nr 2514.

Gazeta Muzyczna, [b.a.], „Ruch Muzyczny” 1861, nr 10.

Joseph Wieniawski, [b.a.], ,Der Klavier-Lehrer” 1908, nr 24.

Józef Wieniawski, [b.a.], „Ruch Muzyczny” 1858, nr 7.

Ker, Grand Duo Polonais pour Violon et Piano concertant composé par les frères Henri et Joseph Wieniawski, „Signale für die Musikalische Welt" 1855, nr 31.

Kleczyński J., Ruch Muzyczny, „Bluszcz” 1868, nr 51.

Kleczyński J., Ruch Muzyczny, „Bluszcz” 1871, nr 13.

Kleczyński J., Ruch Muzyczny, „Bluszcz” 1871, nr 18.

Kleczyński J., Ruch Muzyczny, „Bluszcz” 1876, nr 16.

Kleczyński J., Nowości Muzyczne, „Echo Muzyczne, Teatralne i Artystyczne" 1886, nr 128.

Kleczyński J., Nowości Muzyczne, „Echo Muzyczne, Teatralne i Artystyczne" 1886, nr 141.

Kleczyński J., Nowości Muzyczne, „Echo Muzyczne, Teatralne i Artystyczne" 1891, nr 390.

Kleczyński J., Józef Wieniawski, „Echo Muzyczne i Teatralne” 1884, nr 36.

Kleczyński J., Koncert Józefa Wieniawskiego, „Echo Muzyczne, Teatralne i Artystyczne" 1885, nr 81.

Kleczyński J., Ze świata muzycznego, „Tygodnik Ilustrowany” 1869, nr 57.

Nowości Muzyczne [b.a.], „Kłosy” 1888, nr 1190.

Koncert Pana Józefa Wieniawskiego, [b.a.], „Ruch Muzyczny” 1858, nr 10.

Koncert Pana Józefa Wieniawskiego w Resursie Kupieckièj, [b.a.], „Ruch Muzyczny" 1858, nr 13.

Koncert pp. J. Wieniawskiego, Al. Reicharda i Ad. Hermana, „Ruch Muzyczny" 1858, nr 51.

„Kurier Warszawski” [b.a.] 1876, nr 207.

„Kurier Warszawski” [b.a.] 1876, nr 219.

„Kurier Warszawski” [b.a.] 1877, nr 211.

„Kurier Warszawski” [b.a.] 1877, nr 218.

„Kurier Warszawski” [b.a.] 1878, nr 290. 
„Kurier Warszawski” [b.a.] 1896, nr 105.

„Kurier Warszawski” [b.a.] 1896, nr 109.

Le Journée, [b.a.], „L'Europe” 1882, nr 917.

Leipzig, [b.a.], „Musikalisches Wochenblatt” 1910, nr 13.

Leitzmann A., Joseph Wieniawski Sonate pour Piano op. 22, „Die Musik” $1909, \mathrm{nr} 4$.

Les peintres belges au salon, [b.a.], „L'Art Moderne” 1884, $\mathrm{nr} 25$.

„Morning Post" [b.a.] 1891, nr 37.112.

N., Joseph Wieniawski, „Musikastetische Betrachtungen” 1909, nr 4.

Nouvelles, [b.a.], „Revue Gazette Musicale de Paris” 1860, nr 53.

Nouvelles diverses, [b.a.], „Le Guide Musical” 1884, $\mathrm{nr}$ 34-35.

Nouvelles diverses, [b.a.], „Le Guide Musical” 1884, nr 37.

Nouvelles diverses, [b.a.], „Le Guide Musical” 1884, $\mathrm{nr} 43$.

Nouvelles diverses, [b.a.], „Le Guide Musical” 1887, nr 26-27.

Nouvelles diverses, [b.a.], „Le Guide Musical” 1887, nr 52.

Nouvelles diverses, [b.a.], „Le Guide Musical” 1895, $\mathrm{nr} 15$.

Nouvelles diverses, [b.a.], „Le Guide Musical” 1895, nr 23-24.

Nouvelles diverses, [b.a.], „Le Guide Musical” 1898, nr 48.

Nouvelles diverses, [b.a.], „Le Guide Musical” 1899, $\mathrm{nr} 37$.

Nouvelles diverses, [b.a.], „Le Guide Musical” 1899, nr 45.

Nouvelles diverses, [b.a.], „Le Guide Musical” 1900, $\mathrm{nr} 11$.

Nouvelles diverses, [b.a.], „Le Guide Musical” 1903, nr 6.

Nouvelles diverses, [b.a.], „Le Guide Musical” 1910, $\mathrm{nr} 46$.

Nouvelles diverses, [b.a.], „Le Guide Musical” 1911, nr 7.

Nowości Muzyczne, [b.a.], „Echo Muzyczne i Teatralne” 1884, nr 56.

Nowości Muzyczne, „Echo Muzyczne, Teatralne i Artystyczne” [b.a.] $1887, \mathrm{nr} 183$.

Nowości Muzyczne, „Echo Muzyczne, Teatralne i Artystyczne” [b.a.] 1887, nr 222.

Paris et départements, [b.a.], „Le Ménestrel” 1911, nr 23

Petite chronique, [b.a.], „L'Art Moderne” 1884, $\mathrm{nr} 4$.

Petite chronique, [b.a.], „L'Art Moderne” 1884, nr 43.

Petite chronique, [b.a.], „L'Art Moderne” 1886, nr 1.

Petite chronique, [b.a.], „L'Art Moderne” 1886, nr 8.

Petite chronique, [b.a.], „L'Art Moderne” 1887, nr 2.

Petite chronique, [b.a.], „L'Art Moderne” 1887, nr 13.

Petite chronique, [b.a.], „L'Art Moderne” 1888, nr 47.

Petite chronique, [b.a.], „L'Art Moderne” 1895, nr 16. 
Petite chronique, [b.a.], „L'Art Moderne” 1897, nr 13.

Petites Nouvelles, [b.a.], „Le Figaro” 1887, nr 140.

Petites Nouvelles, [b.a.], „Le Figaro” 1893, nr 101.

Petites Nouvelles, [b.a.], „Le Figaro” 1893, nr 135.

Petites Nouvelles, [b.a.], „Le Figaro” 1904, nr 100.

Province, [b.a.], „Le Guide Musical” 1885, nr 49.

Przegląd Muzyczny, [b.a.], „Ruch Muzyczny” 1860, nr 19.

Revue des theatres, [b.a.], „Le Petit Journal” 1882, nr 7001.

Salle Pleyel, [b.a.], „Le Guide Musical” 1911, nr 26-27.

Soirées et concerts, [b.a.], „Le Ménestrel” 1860, nr 27.

Soirées et concerts, [b.a.], „Le Ménestrel” 1860, nr 28.

Soirées et concerts, [b.a.], „Le Ménestrel” 1895, nr 19.

Soirées et concerts, [b.a.], „Le Ménestrel” 1908, nr 2.

Soirées et concerts, [b.a.], „Le Ménestrel” 1908, nr 11.

"The Daily Telegraph” [b.a.] 1899, $\mathrm{nr} 13.730$.

"The st. James's Gazette" [b.a.] 1891, nr 3443.

Trzeci koncert p. Józefa Wieniawskiego, [b.a.], „Ruch Muzyczny” 1858, $\mathrm{nr} 15$.

Urbański A., Korespondencye Echa, „Echo Muzyczne, Teatralne i Artystyczne" 1885, nr 110. 